\title{
Why Did The Monkey Kill the Giant? ANother LoOK at MargutTe's Death
}

\author{
Pina Palma
}

\begin{abstract}
Summary: In the Morgante through Margutte's death-by-laughter Pulci voices a caustic critique of Ficino's philosophical theories while obliquely denouncing Lorenzo de Medici's acceptance of them. The spectacle of the monkey wearing and taking off Margutte's boots follows Aristotle's definition of the ridiculous that ignites hilarity. It also retrieves Bergson's idea of a society that can be derided because of its attempts to disguise its true self. Most importantly, it reintroduces Petrarch's concepts of similitudo and identitas. Through the depiction of the giant's death Pulci reveals the dignity of a poet remaining true to his poetic discourse even while coming to terms with the negative turn his career has taken.
\end{abstract}

In canto 19 of Pulci's epic poem the adventures of Morgante and Margutte come to a halt when Margutte unexpectedly dies. As is well known, this occurs after the two friends have freed Florinetta from her captors and returned her safely home. The honours and lavish banquets with which the giant Morgante and the half-giant Margutte are regaled by her family, and the long journey they undertake after leaving her home, add to the sense of fatigue Margutte experiences. Near a fountain in the woods, a tranquil setting that evokes an impending crucial event, an exhausted Margutte "Ch'avea ancor ben pieno il sacco, / s'addormentò come affannato e stracco." 1 To poke fun at him while he sleeps Morgante removes and hides Margutte's boots. Then he awakens him. Margutte immediately realizes that his boots are missing. Light-heartedly, Morgante explains that he has hidden them to avenge the "countless wrongs" Margutte has inflicted on him. To get them back Margutte must find them. Displaying neither hesitation nor resentment, he begins searching for his boots and discovers, to his surprise, that a monkey has taken them. Before his astounded eyes the animal first puts the boots on, then removes them. At this sight Margutte erupts in peels of laughter. These increase to the point that the half-giant eventually explodes in a painful outburst that kills him.

Margutte's death stuns not only Morgante, but also Pulci's readers. As

1 Pulci, Morgante e le lettere, 144. All future references will be from this edition. 
the direct result of an outbreak of laughter it seems unworthy of the wilful, heroic, albeit bawdy half-giant who has steadfastly journeyed through both pagan and Christian camps, fighting on Morgante's side. Arguably, Margutte's unconventional death could appear as a fitting end for the peculiar traits he personifies. To be sure, his disproportionate body and prodigious appetite not only transgress the boundary between the human and the bestial, the proper and the improper. They especially defy the notion of the harmonious human body that, according to Manetti, Landino, and Alberti, exemplifies a proportional microcosm of perfection. ${ }^{2}$ For the humanists who championed this idea, a well-proportioned body coincides with man's high moral purpose and achievements. Yet Margutte is depicted as lacking both. Is this the reason why Pulci takes his character's life in such a strange way? Or, is it possible that through this unconventional death the poet deliberately challenges his contemporaries and the readers' expectations? One plausible answer lies with Petrarch's description of the lover in Canzoniere RVF 135. I will return to Pulci shortly, but first I want to address the analogy of dying by laughter in Petrarch.

In the canzone Petrarch's poetic imagination lends psychological depth to the dejected lover's palpable suffering. Overpowered by desire for the lady whose sight on a spring morning enraptured him, the lover is not only stripped of his sense of self but also left emotionally vulnerable. Leaving no signifier of his yearning for Laura unexplored, the poet/lover speaks of the beloved in terms of a lady whose compelling beauty, like a magnet capable of dislodging nails from wood, has all but unhinged him. Still, although unrequited love is unbearably painful for him it often turns into sublime torment. By conveying the immediacy of the pining that simultaneously enfeebles and sustains the lover, these vacillations strike a deep emotional chord that goes to the heart of the human condition. A virtuoso of metaphors, Petrarch recreates and illustrates the wavering of his feelings through a series of images among which stands that of the phoenix that dies and is reborn out of its own ashes. Pain and pleasure, a sense of helplessness that turns into power, ardour and hardship that become energy consuming him, all underscore the dramatic tension stirring the lover. While establishing a human connection with the readers, the emotional

2 Alberti, De re aedificatoria, Bk. IX, ch. 5 "For every body consists of parts that are fixed and individual; if these are removed, enlarged, reduced, or transferred somewhere inappropriate, the very composition will be spoiled that gives the body its seemly appearence." See also Trinkaus, "A Florentine Contrast: Manetti and Poggio on the Dignity and Misery of Man," In our Image and Likeness, 23070 . 
swings overpowering the lover give a full measure of the psychological complexity shaping the individual on the threshold of modernity.

Yet the force of this canzone lies in its all-encompassing geographic settings ${ }^{3}$ evoked to provide a vivid prism through which the intensity of human emotions is explored. In far-off lands Petrarch finds scope for his analogies and a canvas for his descriptions. For him no highly mythologized corner of the world-that is neither East nor West, neither Epirus nor Canary Islands-offers a refuge from his anguish. Nor does suffering free him from the amorous yoke. On the contrary, the poet claims that the wondrous nature of exotic marvels found in distant lands matches his emotional restlessness, and this renews his longing for his beloved. Rather than erasing the memory of Laura and diminishing his desire of her, supernatural marvels of far-off places turn into yardstick of his wretchedness. Narcissistically, he equates the qualities of those phenomena to his yearning, because they stir up beautiful memories and pit them against the loneliness and misery he endures in the lover's absence. In a sense, through remote and unknown lands the poet draws the geography of his amorous suffering. Much like Pomponius Mela's De Chorographia, ${ }^{4}$ which-as the name suggests - does not conform to discussions of Roman and Greek geography but focuses instead on drawing a cultural map of Phoenician (his) culture, 5 Petrarch's geographic allusions cut through space and time to probe the wretchedness of his love.

Memory plays a central role in the canzone. First of all, it allows the poet to retrieve and relive his fortuitous encounter with Laura. As it forges a fluid temporal link between past and present, memory breaks the bounds of, and establishes a strong relationship between, the poet's inner and outer worlds. Within the vastness of foreign lands, or to state it more accurately, beyond the boundary of the lover's tormented self, memory establishes, albeit by way of contrast, that reminiscing is a return to the reality of her absence. Places and wonders may change, but not emotional or intellectual needs, just like sensibilities may shift according to human dynamics but

3 On Petrarch and travel, see Cachey, Petrarch's Guide to the Holy Land, especially the introduction, 1-50; "From Shipwreck to Port"; and "Petrarch, Boccaccio, and the New World Encounter."

4 Petrarch brought a copy of this work with him from France. After 1471 more than 150 printed editions circulated. See Mela, Description of the World, 28-29. It is important to remember that unlike the Balearic Islands, the Canary Islands ("isole della fortuna") are never mentioned among the islands discussed in Book 2 of the treatise.

5 See Batty, "Mela's Phoenician Geography," 78. 
not according to personal desires. Like a double-edged sword, memory frees the lover from the bonds of time, because reminiscing about the past allows a provisional escape from the present. At the same time, though, the freedom that memory affords is a constant reminder of the ways in which the present torments the lover. By weaving together locations and marvels and drawing on a vast spatiotemporal map, Petrarch directly juxtaposes the tangible and near with the elusive and distant, or the unpleasant present with the wonderful past: in short, reality with his construed ideal. This multilayered system allows the poet to simultaneously connect and contrast his emotionally charged (pleasure-seeking) inner-world to the concreteness (pleasure-lacking) of external experiences. The contradictions that lie at the heart of this configuration underscore the psychological dislocation between reality experienced from a great distance and one lived in the immediate vicinity. While the distance between Vaucluse - where he lives - and the remote places he describes suggests spatial rather than emotional detachment, there remains in Petrarch's description the more treacherous territory of personal tribulations. These illuminate the contradictions that love foments. In the interplay of his nuanced reflections the poet / lover is left with a profound sense of resignation and anguish. With a tone that is reasoned and careful, never hesitant, Petrarch does suggest that amorous suffering is worth the happiness it potentially delivers. At the same time, however, the awareness that his suffering begets no hope overpowers all other thoughts. The canzone's last stanza makes it clear that the possibility of his love being reciprocated is unequivocally unattainable.

The "Isole della Fortuna"6 are among the places Petrarch mentions because of two springs located there. According to the poet, of the springs "chi de l'una / bee, mor ridendo; et chi dell'altra, scampa" (78-79). By underscoring anew and with remarkable inventive modulation the emotions that fluctuate between two extremes, like waters in streams that flow and ebb, this image complements and strengthens the description of the poet who incarnates amorous anguish. In the verses that follow, he claims that the springs' powers exemplify the predicament in which he finds himself. Namely, if it were not for the grief Laura's absence causes him, he could die-metaphorically—of the joyous laughter ${ }^{7}$ that the pleasure of loving her affords. The springs' intoxicating waters and their touted powers re-contextualize the poet's undiluted and patient suffering. But because

6 See Cachey, Le isole fortunate.

7 On different types of laughter in Greek philosophical works, see De Vries, "Laughter in Plato's Writings," 378-81. 
a joyous death is denied him, he is consumed by a life of tears. Petrarch's canzone leaves no doubt as to the convergence of sorrow and joy, forces that tear apart the poet/lover. And as he grapples with them, there unfolds the nuanced dramatization and subtle provocation of an existence that is denied the possibility of redemption and renewal through earthly love.

Separate lives interconnect, sometimes powerfully, and poets have a fascinating way of dialoguing with each other across centuries. Petrarch's lover's unattainable death-by-laughter is precisely the one Pulci's Margutte experiences. Might the unusual end of a XV century Italian literary hero suggests, at the very least, that its author with piercing inventiveness is interweaving Petrarch's poetic elaboration into his own work? Could this insinuate the possibility that the lover's suffering has as counterpart the giants' (and Pulci's through them) sense of isolation? Surely, while for the first this feeling reflects the absence of the beloved, for the latter it mirrors the distance from the friend and patron. More specifically, just like the giants' physical traits set them apart from the ideals the elite champions, the poet's fallout from Lorenzo's grace marks his disenfranchisement from court. The raw and genuine agony that pulses through Pulci's poetry, letters, and Morgante leaves no doubts as to the poet's emotional attachment to his patron. Still, like the poet/lover of Canzone 135, Pulci is pulled by two opposing forces: his fondness for Lorenzo and his loathing for Franco and Ficino, the two who consolidate their influence within the Medici court by casting Pulci and his works under a negative light. Alienated from Lorenzo, the poet's world fall apart. Disconnectedness, displacement and marginalization cause predictable dismay by redefining his existence in terms of personal and professional unsettlements. Yet over and against this reality, the energy, richness and vibrancy that marked his experience as a court insider, remain a magnet for him. ${ }^{8}$ The loss of friendship entails a loss of patronage, and this dashes the hopes for financial security. Pulci is unable to disprove Ficino and Franco's increasingly provocative calumnies against him;' worse yet, he is unsuccessful in proving to Lorenzo his unyielding loyalty. ${ }^{10}$ Political expediency, more than a sense of responsibility and affection toward the mentor with whom he shared a proclivity for heedless and irresponsible behaviour during his earlier years, forces the heir to the Medici's power to distance himself from the older Pulci. In contrast,

8 He defines it "la corte del paradiso"; cited in Momigliano Lindole e il riso del Pulci, 13.

9 Orvieto, Pulci Medievale, 213-43.

10 Pulci, Morgante e le lettere, 976. 
by moving closer to Ficino's sphere of influence, ${ }^{11}$ Lorenzo can reap political benefits that bolster his political ascent.

The ravaging sense of hopelessness and rejection that at first overwhelms Pulci, not unlike Petrarch's amorous experience, contrasts with the memories of a happier past. For him, as for Petrarch, those memories jar with the tragedy of parting and separation, and this exacerbates his bitterness against his detractors. A sense of defeat characterizes his existence, leading him to believe that life is a practical journey, and not a philosophical exercise or a pleasurable certainty. ${ }^{12}$ His bristling resentment toward Ficino and Franco sparks off his acerbic critique of the ways in which the court, through its prince, fosters brutal deceit, fluid treachery, and a voracious craving for power. By focusing on the wicked capriciousness of human nature rather than on philosophical theories, as Ficino would have, Pulci through his characters exposes the meaninglessness of philosophical knowledge. With the likelihood of a return to the court made inconceivable with the turn of events, the poet remains upbeat about exposing his detractors' manoeuvres to oust him. To accomplish this he is especially driven by the idea of showing their intellectual shortcomings. He borrows from Petrarch's towering authority, because in a sense, his professional powerlessness, and resignation, mirrors Petrarch's amorous hopelessness. At the same time, however, Pulci gives a twist to Petrarch's model. Margutte's death, the death that escapes the unfulfilled lover, suggests that he (and through him the poet himself) cannot be reduced to a life of grief. As the embodiment of the poet, Margutte shows the same traits that the poet is accused of possessing: he is a non-believer, inclined to a dissolute life, lover of pleasures and seeker of material gratifications. Yet also like Margutte, and unlike Morgante, the poet is unflinching in his loyalty to his friend. ${ }^{13}$ As a result, at this juncture Margutte does represent Pulci and dies (metaphorically) of the happiness caused by the spectacle unravelling in front of him. Steeped in the exuberant wonder that comes from observing an unusual occurrence, the bizarreness of this death is matched by the plausibility that Petrarch's elucidation in Canzone 135 lends to it. Through this incident, Pulci ridicules not only the cultural, but also the philosophical certainties disseminated by Ficino and embraced by Lorenzo. With

11 Copenhaver, "Lorenzo, Ficino and the Domesticated Hermes," especially 255. 12 See Momigliano, Lindole e il riso del Pulci, 26-27 and 73-76. See also Ageno, Morgante, vii-xxx.

13 I am thinking specifically of all the instances in which Morgante cheats Margutte out of his fair share of food as they journey together in Canto 19. 
sober attentiveness, the poet exposes the increasing narrowness of his nemesis's theories. Margutte can die of laughter because he has before his eyes not the object of his sensual desires—as Petrarch would have wished for himself. Rather, the half-giant, like Pulci the flea, has the truth about his opponents revealed in a spectacle that fuses wit with knowledge, imitation with inventiveness. In a wonderful confluence of unexpected connections, Margutte's laughter results from the excitement of observing the monkey that in Pulci's construal personifies Ficino.

According to Ficino, a man deserving of admiration and love must possess "the most vigorous and acute faculties," along with "a handsome form, well proportioned limbs and a noble stature." He must also "speak(s) elegantly [...] and laugh(s) graciously" (gratiose ridentem). For the philosopher, the body's harmonious proportionality is the measure of male handsomeness; to this a manly polite, moderate and gracious laughter, not a boisterous one, is most fitting. According to the medical theories Ficino expounds in his De vita libri tres, this type of mirth does not drain the spirit of vital energy. "At every age" the philosopher argues, "it is especially conducive to life to retain something of your childhood and always to strive for a variety of pleasures - but not a long, immoderate laughter, for it extends the spirit too much." 14 With a more radical postulation, however, and in the wake of Neoplatonic cosmology, Ficino in his Quid sit lumen claims that the heavens' cosmic radiance is the manifestation of heavenly mirth. By asserting: "light in the fabric of the world is a kind of heavenly mirth arising from the delights of the gods," 15 the philosopher not only links light to God but also associates laughter with spiritual pleasure. This theory enables him to argue that "fullness of joy," is another attribute of perfect celestial spirits, and that this is made visible by and through light. The laughter that celestial spirits radiate to celestial bodies, Ficino claims, comes down to humans. Through this, he makes human laughter an extension of divine laughter and both of these, he explains, are the expression of temperate, gracious pleasure because pleasure, in his construct, is Grace. ${ }^{16}$ In his Philebus Commentary, Ficino makes a clear distinction between short-lived joys derived from sensual pleasures and the fuller ones attained by the soul that has knowledge of God. ${ }^{17}$ For him, this latter kind of joy guides humanity through its ascent from the earthly to spiritual; and this

${ }^{14}$ Ficino, Three Books on Life, 15-20.

15 Ficino, Quid sit lumina, 2:35.

16 See O’Rourke-Boyle, “Marsilio Ficino’s Gracious Laughter," 52, 3, 721.

17 Ficino, Philebus Commentary, 113. 
exemplifies the ultimate good, truth, and beautiful. Accordingly, the gracious laughter Ficino discusses is inspired by a desire to participate in the spiritual fullness that divine grace infuses.

Undoubtedly, Margutte's laughter scratches the lustrous surface of Ficino's theories. From the fortuitous first encounter between him and Morgante, Margutte explains that three words "la gola, il culo e 'l dado"18 constitute the philosophical / theological axiom upon which he bases his faith. With these "virtues" the half-giant-and, through him, Pulcisweeps away Ficino's discourse on beauty, grace, and love ${ }^{19}$ that idealizes man's godlike figure and potential. Specifically, Margutte's credo strikes at the heart of the allegedly purifying effect that, according to Ficino, moral virtues have in guiding man's ascent to God for it places the body instead of the intellect at the center of man's source for pleasure. By substituting the Christian cardinal virtues with his personal version of them, namely gluttony, sex, and gambling, Pulci mocks Ficino by rejecting his idea that man's happiness is achieved through contemplation and philosophical knowledge. ${ }^{20}$ In Pulci's view, the philosopher's unyielding belief in the moral life of the individual ${ }^{21}$ that emphasizes intellectual pursuits and leads to a system of political and cultural propriety shuns the natural and practical aspects of human life. Trading abstract philosophy with practical knowledge, Pulci rejects the idea of reducing human experience to tessere of a vaster, theologically minded and philosophically oriented mosaic. Through this, he also demonstrates that as human desires cannot be bridled by theological beliefs, so poetic genius cannot be controlled by codified philosophical trends ${ }^{22}$ that saturate society and further divide the intellectual elite

18 Pulci, Morgante, XVIII, 32.

19 Mazzotta, Cosmopoiesis, 8.

20 Kristeller, Renaissance Thought II, 106.

21 Ficino, Theologia Platonica XIV, 1 "So the aim of our soul's whole endeavour is to become God. Such an endeavour is no less natural to men than the effort to fly is to birds; for it is always and everywhere present in all men. So it accompanies the nature itself of man the species and not just the contingent quality of a particular man." See also Trinkaus, 171-200.

22 There is an echo here of Alberti's belief in expanding the thematic field beyond what is included and known; Alberti, On Painting, Bk II, p. 72 "Composition is the rule of painting by which the parts of the things seen fit together in the painting. The greatest work of the painter in not a colossus, but an istoria. Istoria gives greater renown to the intellect than any colossus....in this composition of planes grace and beauty of things should be intensely sought for." 
from common people. Like Petrarch, Pulci believes that the beauty of poetic images and expressiveness lies on the dynamic connection between thoughts and words. The expert combination of the two, the cleverness of an original idea articulated through elegantly structured verses reveals the poet's greatness and tells him apart from those unable to develop and refine their own thoughts. For Pulci the belief in man's attainment of earthly pleasures not only pulls the thread of Ficino's theological fabric, but also upends Valla's Epicurean notion of uti and frui according to which the enjoyment of the senses is a prelude to higher pleasures of the soul 23 that arouse man's interest in civic responsibilities and lead to celestial happiness. None of these possibilities colors the contours of Margutte's faith. In a reversal of theories, his faith parodies Ficino's intellectual haughtiness. Ironically, it is this jocularity and love for trespassing the boundaries of the norms that originally determined Pulci's close friendship with Lorenzo.

If the world of physicality shapes Margutte's faith into a theory of selfserving indulgence, it also moulds the "modern" self-assured man in a way that is found neither in Valla nor in Ficino's writings nor, for that matter, in Lorenzo's own writings. This man is undeterred by the lack of confidence and fragility that paralyzed his predecessors. Unlike the old social model, Pulci's modern man explores the ways in which he can face the challenges of the world because his interests - and gratifications - are neither pinned to intellectual pursuits nor postponed to the afterlife. On the contrary, they are inscribed within the ever-fluctuating possibilities of the pragmatic universe he inhabits and by which his experiences are shaped. Significantly, Morgante's materialistic credo mirrors the reality of power: a fact with which both Ficino and Lorenzo, in their respective positions, are comfortably familiar. This suggests that for the giant-as for prince and subjects alike-desire for power can be reduced to - and is synonymous with-yearning to possess the tangible, even though this entails closing the eyes to justice. This implication zeroes in on a central contradiction of Ficino's theological position; it also reveals man's limitations not only as his failure to govern himself but, especially, as his failure to govern others. Margutte's apparently self-indulging creed, revolving around the enjoyment of the senses that according to Valla plague the mind but that are also a source of pleasure, ${ }^{24}$ becomes more complex as political nuances of power emerge from it.

By defying Ficino's idea of a disciplined, graceful mirth, Margutte's

23 Lorch, A Defense of Life, 267.

24 Lorch, A Defense of Life, 89. 
unrestrained laughter suggests Pulci's understanding of a world ruled by impulses. 25 That the laughter is provoked by the incredible spectacle of the monkey putting on and taking off the boots follows Aristotle's definition of the ridiculous that ignites hilarity. This implicitly gives a clear sense of the chasm between the high cultural sophistication established at Lorenzo's court and the unruly, unsophisticated, incompatible individuals shaping society outside of it. For Lorenzo closing his eyes to the more concrete, unaffected vision of the world brings him closer to achieving his political goals. Pulci, on the contrary, detects in his former patron's attitude the forced distance the prince places between "insiders" and "outsiders." This, the poet concludes, only exacerbates the political tensions simmering in Florence because the great elegance of bearing and beauty of thoughts that the Medici house flaunts masks the rawness of its corruption.

According to Henry Bergson, a society that tries to disguise its flaws is always the object of laughter because masking shortcomings produces the opposite results, thus highlighting the very elements that it endeavours to suppress. ${ }^{26}$ In Bergson's view, the opposite of comical is grace. ${ }^{27}$ This may appear to retrieve Ficino's notion of manly laughter; yet grace for Bergson has different implications. It suggests, among other things a society's confident resolve to sort out and tackle its flaws rather than concealing them. Because of this, more than the Bergsonian echo of the ridicule a society is subjected to when it attempts to disguise its true traits and which applied to Pulci's Florence speaks of the court's intellectual aloofness, the image of the monkey the poet relies upon while patently comical is also reflective of an essential truth-the court is a universe in which the arbitrary becomes normal, and deceit disempowers truth. Populated by impostors and dissimulators who are disappointingly unimaginative and who seek to advance their personal interests, it becomes the cradle of ambitions that lack solid foundations. Its poetasters, philosophers, and theologians remedy their shortcomings by translating, imitating and reproducing the works and styles of others, thus trampling on the ideal tenets they ostensibly champion.

The concepts of similitude and copy (similitudo and identitas) occupy

\footnotetext{
25 Getto speaks of the poem as one that "accoglie non solo la poetica antiascetica del suo tempo, ma un largo repertorio di attegiamenti beffardi, o di temi eterodossi, [...] e accetta pure il contegno dell'antico rispetto e dell'ingenuo abbandono." Studio sul Morgante, 197

26 Bergson, Le rire, 45.

27 Bergson, Le rire, 29.
} 
a conspicuous place in Petrarch's letters. Familiares XXIII, 19, is of particular interest because in it the writer attacks uninspired poets and writers who make use of and appropriate ideas conceived by others and articulate them in styles borrowed from still other writers. To describe these authors Petrarch uses the image of a monkey because, the poet argues, they lack not only imagination, but also the ability to express ideas with their own words and uncommon beauty. Consequently, they imitate great models but attempt to mask their doings by piecing together concepts and styles used in the past by others. Addressed to Giovanni Boccaccio, a detail underscoring the significance Petrarch attaches to the topic, speaking, as it were, from poet to poet, the letter focuses on the qualities Petrarch's assistant possesses. The originality of thought and expository style the young man shows are for Petrarch strong proof of his literary acumen. A lack of interest in wealth and materiality, the poet argues, matches his assistant's seriousness of purpose. Also, his concern with maintaining and defending the primacy and legitimacy of ideas and techniques of a few great authors against the incompetence, complacency, and lack of poetic vision of the many, evidences the young man's potential to develop a unique poetic style. In Petrarch's view, rather than imitating the works of others, a true poet consistently and incisively articulates ideas, sustaining them with clarity and effortless sobriety that alternates excitement and introspection much like what he does in Canzone 135. Thus a poet becomes an interlocutor rather than an imitator.

The ability to echo an idea conceived by another poet without imitating it is for Petrarch the equivalent of the son that resembles and yet is not the same as the father. ${ }^{28}$ Petrarch argues that poets must toil to refine and filter what they draw from others as they develop their own styles. In this fashion, he reasons, readers are able to discern the echoes of other poems without pointing to specific verses because the ingenio and colorito of other poets can be adopted but their expressions and words (abstinendum verbis) cannot. The first practice, Petrarch maintains, pertains to the poets, the latter to monkeys (illa poetas facit, hec simias). By copying others (identitas) rather than simply evoking (similitudo) their stylistic achievements, Petrarch claims an author shows his lack of authentic genius, thus demon-

28 "L'imitatore deve cercare di essere simile, non uguale, e la somiglianza deve esser tale, non qual'è quella tra l'originale e la copia, che quanto più è simile tanto più è lodevole, ma quale è tra il padre e il figliuolo. Questi infatti, sebbene spesso siano molto diversi d'aspetto, tuttavia un certo non so che. [...] Si rivela [...] (e) produce quella somiglianza, la quale fa sì che subito, vedendo il figliuolo, si ricordi il padre." Petrarch, Opere, 1233. 
strating his unimaginative mediocrity. Though he never explicitly states it, for Petrarch the poet is a wordsmith capable of forging unique lyrical systems that, by transporting the human mind to all sort of foreign lands, shape original system of thoughts. And through these, plumb the depth of the human condition.

The etymology of the word simia retrieves both the idea of copying and emulating. For this reason, Dante uses the image of the monkey in Inferno XXIX. In the circle of falsifier the poet encounters Capocchio, an alchemist and counterfeiter of metals, who describes his earthly life as one in which "fui di natura buona simia." Generally, medieval bestiaries attribute negative traits to this animal. ${ }^{29}$ Foolishness, wantonness, lust, gluttony, and drunkenness, in short the whole gamut of temptations unleashed by the senses, are among them. With the exception of the first, these characteristics describe both Morgante and Margutte. Of course, they also depict the Medicean universe. For the two traveling companions, the encounter with the monkey is, for this reason, a coming face-to-face with the system and vices it typifies and they personify. Not surprisingly, as they come up against the monkey, Morgante is enthralled to it, laughs about it with Margutte, but does not die. This is possible because through his baptism, Morgante has espoused the ideals of the courtly universe, whereas Margutte remains untouched by, and is a living antithesis to, them. This, however, does not mean that Margutte does not understand them.

As a result, for Margutte, who holds the fantastically ludicrous in front of him, the monkey that wears his boots on-and-off, 30 represents the evisceration of truth. In other words, for him the monkey's antics bring to light the opportunistic nature of the lifestyle he rejects. The farce he witnesses turns, for this reason, into a re-enactment of the behaviours that the court champions. Like Pulci, who was ousted by an unskilled poet and expert imitator, Margutte dies because of a practical joke his egocentric friend inflicts on him. This informal, candid scene that almost seems to color with superficial frivolity the half-giant's death is in fact a genuine, coherent attempt to redefine the poet's existence in view of his new circum-

29 Janson, Apes and Ape Lore in the Middle Ages and the Renaissance. See especially, the ape as sinner and fool (29-31), as personification of Lust "The Ape and the Fall of Man," (107-44); the ape as Taste "The Ape, the Senses, and the Humours" (239-59); the ape as imitator "Ars Simia Naturae" (287-325); and the ape representing drunkenness (242-44).

30 According to Stefano Carrai, the fact that the boots have spurs confers a diabolic character to Margutte. See Carrai, Le muse dei Pulci, 109. 
stances. Without doubt, by choosing the monkey wearing the boots as the cause of death, Pulci retrieves the vast repertoire of medieval bestiaries that enjoyed high popularity in the Renaissance. Among these, Richard de Fournival's Bestiarie d'Amour $(19,3)$ is of particular interest because it describes the way in which monkeys are captured. By intentionally wearing and taking off shoes where the monkey can see him, the hunter ignites the animal's interest. He then leaves the shoes and hides. The animal immediately tries to emulate him. But as soon as it has even one shoe on, the monkey cannot run away to escape the hunter; and this ensures its capture. Although de Fournival's account is intended to describe man's amorous imprisonment, its implications shed light on the Margutte's death. First, in a reversal of roles, Morgante hides the boots and the monkey finds them. This suggests an inversion between hunter and prey. The monkey is not the one captured, Margutte is; thus in Pulci's story the potential hunter becomes the victim. This is an intriguing shift, because up to this point Margutte has been described as an experienced huntsman and predator. This detail suggests anew the fact that Margutte at this juncture personifies Pulci-the dangerously mischievous poet, victim of others' political ambitions. From this perspective, the analogy of the captive of love that de Fournival draws from the monkey's capture when applied to Margutte, hints at Pulci's loyalty toward Lorenzo. This is to say that, as the prisoner / victim of love, Margutte / Pulci remains captive of Lorenzo's unreciprocated affection.

Viewed from Petrarch's stance, Pulci's monkey positions Margutte's death in the wider and more profound context of ideas and discoveries that have a literary antecedent, but that are carefully sifted through the author's genius. Indeed, by relying on the image Petrarch uses to ridicule mediocre poets and thinkers with refreshingly mordant wit, Pulci voices his criticism of court sycophants. Still, in his criticism of Ficino's writings the spectre of Petrarch's monkeys looms large. Through it, the poet charges the translator, philosopher, poet, and theologian, not only of lacking a personal writing style, but especially of lacking ideas. He also accuses Ficino of imitating and synthesizing the ideas of others. In the cultural revival of Laurentian Florence (1460/70), Ficino's attempt to recapture the "golden culture" experienced in ancient times relied heavily on various poetical, philosophical, and mythical sources. His translations of Greek works, his fusion of Platonic philosophy and Christian theology, his compendium of medical and astrological treatises aimed at recovering ancient Christianity, and the reestablishment of a linguistic semblance of the ancients, all lend themselves to this criticism. The belief that poetry is a type of divine mad- 
ness (as Plato had argued in the Phaedrus) and that only a philosophical content paired with a refined style could raise it to the high level of a golden culture, yet again makes Ficino rely on models set by others. The imitation of Roman as well as Tuscan poets and the fusion of their styles, he contends, are necessary to elevate contemporary poetry to the levels achieved by earlier poets. In Ficino's view Pulcis poetry could not possibly exemplify high culture as it lacks philosophical content. Disagreeing with this position and demonstrating, instead, that it is Ficino who is short of insightfulness and ideas, Pulci-the flea that conceives of the epic half-giant Margutte has the latter laugh of uncontrollable joy at the sight of the little monkey who wants to imitate giants and makes itself ridiculous in the eyes of a knowledgeable onlooker. This laughter is Pulci's laughter. Through Margutte's death by laughter Pulci suggests that Ficino's pedantic influence on the intellectual life of Florence has stifled creativity.

Like the giant who dies happily because he is witnessing the monkey's ridiculous impersonation of a man, the poet is declassed because his poetry is not formulaic but concrete and immediate. It is aimed at probing the wounds of human nature not suturing them by way of imitating the poetic past. Reading between the lines of Margutte's death, it appears that despite the banishment from court the dignity of a poet finally coming to terms not only with inevitability, but especially with the turn his career has taken, does not prevent him from exposing the truth of that court and questioning the connection between power and poetry while remaining true to his poetic discourse.

\section{SOUTHERn CONNECTICUT STATE UNIVERSITY}

\section{Cited Works}

Ageno, Franca. Luigi Pulci. Morgante. Milan, Naples: Riccardo Ricciardi Editore, 1955.

Alberti, Leon Battista. On the Art of Building in Ten Books. Josepf Rykwert, Neal Leach, and Robert Tavernor, trans. Cambridge, MA and London, England: MIT Press, 1999.

The Ten Book of Architecture (De arte aedificatoria). The 1755 Leoni Edition. New York: Dover Publications, 1986.

On Painting. John R. Spencer, trans. New Haven and London: Yale University Press, 1956.

Batty, Roger. "Mela’s Phoenician Geography." The Journal of Roman Studies 90 (2000): 70-94.

Bergson, Henri. Le rire, Essai sur la signification du comique. Paris: Librairie Félix Arcan, 1930. 
Cachey, T.J. "From Shipwreck to Port: RVF 189 and the Making of Canzoniere." Modern Language Notes 120:1 (2005): 30-50.

—. Le isole fortunate. Appunti di storia letteraria italiana. Rome: L' "Erma" di Bretshneider, 1995.

. "Petrarch, Boccaccio, and the New World Encounter," Stanford Italian Review: Perspectives on the Italian Renaissance 10 (1991): 45-59.

Petrarch's Guide to the Holy Land. Notre Dame, IN: University of Indiana Press, 2002.

Carrai, Stefano. Le muse dei Pulci. Studi su Luca e Luigi Pulci. Naples: Guida, 1985.

Copenhaver, Brian P. "Lorenzo, Ficino and the Domesticated Hermes." Lorenzo Magnifico e il suo mondo: Convegno internazionale di studi (Firenze 9-13 giugno 1992). Ed. Gian Carlo Garfagnini. Florence: Leo S. Olsckhi, 1994.

de Fournival, Richard. Bestiarie d'Amour. Suivi de la réponse de la dame. Publié pour la première fois d'après le manuscrit de la Bibliothèque impériale par C. Hippeau. Genève: Slatkine Reprints, 1969.

De Vries, G. J. “Laughter in Plato’s Writings.” Mnemosyne. 38:3-4 (1985): 378-81. Ficino, Marsilio. Philebus Commentary. Ed. and trans. Michael J.B. Allen.Berkeley: University of California Press, 1975.

Quid sit lumina, translated from Latin by members of the Language Department of the School of Economic Science, London. London: Shepeheard-Walwyn, 1975.

Theologia Platonica. Tarns. Michael J. B. Allen. Cambridge, MA and London, UK: The I Tatti Renaissance Library, Harvard University Press, 2004. . Three Books on Life, (De vita libri tres). Trans. and ed. Carol V. Kaske and John R. Kaske. Tempe, AZ: ACMRS, 2002.

Getto, G. Studio sul Morgante. Florence: Leo S. Olschki, 1967.

Janson, Horst, Woldemar. Apes and Ape Lore in the Middle Ages and the Renaissance. London: Warburg Institute, University of London, 1952.

Kristeller, Paul Oskar. Renaissance Thought II. Papers on Humanism and the Arts. Harper Torchbooks / The Academy Library. New York, Evanston and London: Harper \& Row Publisher, 1965.

Lorch, Maristella De Panizza. A Defense of Life: Lorenzo Valla's Theory on Pleasure. München: Wilhelm Fink Verlag, 1985.

Mazzotta, Giuseppe. Cosmopoiesis, The Renaissance Experiment. Toronto: Toronto University Press, 2001.

Mela, Pomponius. Description of the World. Trans. F. E. Romer. Ann Arbor, MI: The University of Michigan Press, 1998.

Momigliano, A. Lindole e il riso del Pulci. Rocca San Casciano: Licinio Cappelli, 1907.

O'Rourke-Boyle, Marjorie. "Marsilio Ficino's Gracious Laughter." Renaissance Quarterly 52:3 (1999): 712-41.

Orvieto, Paolo. Pulci Medievale. Studio sulla poesia volgare del Quattrocento. Rome: Salerno Editrice, 1978.

Petrarca, Francesco. Canzoniere. Turin: Einaudi, 1964. 
Opere. Familiarium rerum libri XXIII. Trans. Mario Martelli. Florence: Sansoni, 1975.

Pulci, Luigi. Morgante e le lettere. Ed. Domenico De Robertis. Milan: Mondadori, 1984.

Trinkaus, Charles. In Our Image and Likeness. Humanity and Divinity in Italian Humanist Thought. Notre Dame, IN: Notre Dame University Press 1995. 